\title{
МІЖДИСЦИПЛІНАРНА ІНТЕГРАЦІЯ ПРИ ВИКЛАДАННІ БІОХІМІЇ У ФАРМАЦЕВТИЧНОМУ КОЛЕДЖІ НА ПРИКЛАДІ ТЕМИ «ВСТУП ДО ОБМІНУ РЕЧОВИН ТА ЕНЕРГІЇ»
}

\author{
I. O. Pershko, N. A. Todosiichuk \\ Zhytomyr College of Pharmacy, Zhytomyr Regional Council \\ INTERDISCIPLINARY INTEGRATION IN THE TEACHING OF \\ BIOCHEMISTRY IN THE PHARMACEUTICAL COLLEGE ON THE \\ EXAMPLE OF THE TOPIC “INTRODUCTION TO THE METABOLISM \\ AND ENERGY”
}

\begin{abstract}
Анотація. У статті проаналізовано теоретичні та практичні аспекти міждисциплінарної інтеграції при викладанні біологічної хімії. Розглянуто механізм реалізації предметно-орієнтованого навчання в межах вертикальної міждисциплінарної інтеграції на прикладі теми «Вступ до обміну речовин та енергії». Запропоновано конкретні шляхи підвищення ефективності викладання біохімії засобами міжпредметних зв'язків.

Реалізація принципів міждисциплінарної інтеграції під час проведення лекційних занять вимагає від викладача глибоких знань не лише його предмета, але й багатьох інших навчальних дисциплін, у тому числі і предметів фахової підготовки студентівфармацевтів. Вкрай важливо дотримуватися оптимального балансу між матеріалом теми, що вивчається під час лекції, та інформацією суміжних тем чи навчальних дисциплін. Використання принципів міждисциплінарної інтеграції при вивченні біологічної хімії сприяє підвищенню мотивації студентів, а саме усвідомленню практичної значущості навчального матеріалу та набутих компетентностей у майбутній професійній діяльності.
\end{abstract}

Ключові слова: міждисциплінарна інтеграція; біологічна хімія; обмін речовин та енергії.

Abstract. The present article deals with the theoretical and practical aspects of interdisciplinary integration in the teaching of biological chemistry. The mechanism of implementation of subject-oriented learning within the frame work of interdisciplinary vertical integration on the example of the topic "Introduction to the metabolism and energy" is considered. Specific ways to improve the effectiveness of teaching biochemistry through cross-curricular communication are suggested.

The implementation of the principles of interdisciplinary integration during lectures requires the teacher of deep knowledge not only of his subject, but also of many other basic disciplines, including subjects of professional preparation of students-pharmacists. It is extremely important to strike the right balance between the subject matter taught during the lecture and the related topics or courses. The use of principles of interdisciplinary integration in the study of biological chemistry contributes to the increase of students' motivation, that is the awareness of the practical importance of educational material and acquired competences in their future professional activity.

Key words: interdisciplinary integration; biological chemistry; metabolism.

Вступ. Сучасні освітні тенденції вимагають за досить обмежений термін навчання в коледжі формування у майбутніх фармацевтів цілого комплексу фахових компетентностей, що, у свою чергу, $\epsilon$ можливим лише за умови високоефективної роботи

(c) I. О. Першко, Н. А. Тодосійчук як викладача, так і студента. Важливою проблемою підвищення ефективності навчального процесу була і залишається вмотивованість його учасників. Сучасна наука пропонує цілий спектр психологопедагогічних методів та прийомів для формування і розвитку мотивації до навчальної діяльності. На 
нашу думку, не останнє місце тут належить реалізації принципу міждисциплінарної інтеграції.

У загальнонауковому контексті під інтеграцією розуміють поєднання в єдине ціле частин, елементів і компонентів, які до цього існували окремо [12]. Щодо міждисциплінарної інтеграції, то іï можна визначити як систему відношень між знаннями, уміннями і навичками, що формуються в результаті послідовного відображення об’ єктивних зв’язків із реальністю в засобах, методах і змісті навчальних дисциплін [11].

Актуальність даної теми серед викладачів-дослідників підтверджується великою кількістю публікацій у вітчизняних фахових виданнях. Теоретичні та практичні аспекти міждисциплінарної інтеграції при викладанні у вищих медичних навчальних закладах висвітлюють у працях С. Бухальська, Н. Шамро [3], М. В. Карпець [6], Н. І. Волощук [11], Е. Ю. Рождественський [9], А. Г. Шульгай [10] та інші. Деякі автори обгрунтовують роль міждисциплінарної інтеграції у формуванні клінічного мислення студента [8] або ж досліджують проблему горизонтальної міждисциплінарної інтеграції в системі компетентнісно орієнтованого навчання [7].

Без огляду на таку широку палітру проаналізованих публікацій, можна констатувати відсутність робіт щодо реалізації принципів міждисциплінарної інтеграції при викладанні конкретних тем курсу «Біологічна хімія» саме для студентів фармацевтичних коледжів, які навчаються за освітньо-професійною програмою «Фармація» спеціальності 226 «Фармація, промислова фармація».

Мета статті - розкриття особливостей реалізації міждисциплінарної інтеграції при викладанні курсу «Біологічна хімія» для студентів фармацевтичних коледжів.

Теоретична частина. Навчальна дисципліна «Біологічна хімія» $є$ обов’язковим компонентом освітньо-професійної програми «Фармація» при підготовці фахівців першого (бакалаврського) рівня вищої освіти за спеціальністю 226 «Фармація, промислова фармація» і передбачена навчальним планом у IV семестрі. Мета вивчення даної дисципліни - сформувати системні знання про хімічний склад, структуру, властивості біомолекул, закономірності обміну речовин й енергії на клітинному рівні в нормі та при патології. Досконале оволодіння необхідним базисом знань, вмінь і навичок 3 біологічної хімії закладає основи для подальшого вивчення фахових дисциплін, зокрема фармакології та фармакогнозії. У свою чергу, вивчення курсу біохімії вимагає від студентів вільного оперування інформацією з навчальних дисциплін, що вивчалися раніше або викладаються паралельно, таких, як: неорганічна, органічна та аналітична хімія, фізична та колоїдна хімія, біологія з основами генетики, біологічна фізика з фізичними методами аналізу, мікробіологія з основами імунології, філософія тощо.

Як приклад реалізації предметно-орієнтованого навчання в межах вертикальної міждисциплінарної інтеграції розглянемо вивчення теми «Вступ до обміну речовин та енергії». Відповідно до навчальної програми, дана тема вивчається в другому модулі і передбачає розгляд таких питань:

1. Обмін речовин та перетворення енергії в організмі.

2. Фази вивільнення енергії з поживних речовин. Макроергічні сполуки.

3. Структура і функції дихального ланцюга мітохондрій. Окисне фосфорилювання.

4. Мікросомальне та вільнорадикальне окиснення.

5. Речовини, які впливають на енергетичний обмін у клітинах.

6. Хімічні перетворення у циклі трикарбонових кислот. Субстратне фосфорилювання.

Для підготовки питань, винесених на самостійне опрацювання, студенти працюють з відповідними підручниками, рекомендованими Центральним методичним кабінетом з вищої медичної освіти МО3 України [1, 2, 5].

Загальні закономірності перетворення речовин та енергії в живих організмах вивчаються у шкільному курсі біології, і завдання викладача - перевести вже наявний у студентів базис знань на якісно новий рівень, а саме сформувати чітке та цілісне уявлення молекулярних механізмів обмінних процесів і шляхів їх регуляції.

Оскільки згідно 3 робочою навчальною програмою на розгляд даної теми відводяться лише 2 лекційні години, важливим є оптимізувати роботу студентів та забезпечити максимально ефективне використання аудиторного часу. 3 цією метою під час лекційного заняття студенти використовують заздалегідь роздруковані опорні конспекти, що дозволяє не лише розглянути всі питання теми, але і розв’язати низку проблемних та дискутивних завдань.

Розглядаючи перше питання теми, викладач, перш за все, апелює до вже наявного досвіду студентів з навчальної дисципліни «Біологічна фізика 
з фізичними методами дослідження», яка вивчалася у II семестрі. Зокрема, звертаємося до теми «Термодинаміка біологічних систем», яка розкриває фізичні закономірності функціонування живих організмів - підтримання стаціонарного стану біологічної системи, а отже, i ïï існування, яке є можливим лише за умови безперервного обміну речовиною та енергією з навколишнім середовищем. Також згадуємо поняття про внутрішню енергію dU, яка, власне, і вивільняється у результаті катаболічних перетворень біомолекул. Доцільно також пригадати формулювання першого та другого законів термодинаміки для біологічних систем, до яких звертатимемося при поясненні наступних питань теми.

Водночас у курсі біохімії ми не розглядаємо питання енергетичного ефекту хімічних реакцій, оскільки з механізмом перебігу ендергонічних та екзергонічних процесів студенти детально знайомляться в курсі біологічної фізики та фізколоїдної хімії. Ці ж знання ефективно використовуємо для характеристики макроергічних сполук, які розглядаються у другому питанні.

Вводячи поняття катаболізму та анаболізму, слід звернути увагу студентів на підпорядкування цих процесів універсальним законам діалектики, а саме закону єдності і боротьби протилежностей. Розглядаючи локалізацію перебігу стадій катаболізму біомолекул, використовуємо наявні у студентів знання з анатомії та цитології.

Розглядаючи макроергічні сполуки, вказуємо на лікарські засоби з відповідною діючою речовиною, наприклад, натрію аденозинтрифосфат, який використовується як кардіопрепарат. Також можна згадати про механізм антимікробної дії фурациліну, який базується на блокуванні у бактеріальних клітинах процесу утворення ацетил-КоА з піровиноградної кислоти.

Питання щодо реакцій біологічного окиснення (передує третьому питанню) базується на вже наявному у студентів розумінні механізмів окисно-відновних процесів, яке формується при вивченні неорганічної та органічної хімії. Водночас викладач має звернути особливу увагу на спільні та відмінні риси перебігу цих процесів у живій та неживій природі.

Одним із найскладніших питань даної теми і курсу біологічної хімії загалом є молекулярна організація ланцюга біологічного окиснення (дихального ланцюга) на мембранах мітохондрій. Для розуміння фізичної, хімічної та біологічної суті цього процесу від студента вимагаються глибокі знання будови атома, механізмів окисно-відновних реакцій, структури та функціонування біологічних мембран. Водночас це питання потребує і внутрішньодисциплінарної інтеграції, зокрема розуміння механізмів біологічного каталізу та функціонального значення гемпротеїдів.

Також вивчення цього питання дає великі можливості для формування цілісного уявлення про єдність структури і функціонування життя на Землі та його залежність від енергії Сонця. На жаль, досить низький рівень знань студентів з шкільного курсу біології, а саме брак розуміння механізмів фотосинтетичної діяльності рослин, значно ускладнює це завдання.

Для кращого розуміння принципу роботи ферментативних систем дихального ланцюга мітохондрій під час лекції та на практичному занятті доцільно використовувати комп’ютерні анімаційні ролики, які дозволяють візуалізувати складний молекулярний процес і полегшити його сприйняття та усвідомлення.

Детально розглядаємо енергетичний ефект роботи дихального ланцюга мітохондрій. Важливою проблемою, яка при цьому вирішується, $€$ з'ясування причин та наслідків вивільнення енергії у процесі функціонування ДЛМ. Для розв’язання цієї проблеми студенти використовують вже наявні у них знання з курсу біологічної фізики, а саме поняття про градієнти. Перенесення електронів та протонів від НАДН+ $\mathrm{H}^{+}$та ФАДН ${ }_{2}$ на $\mathrm{O}_{2}$ відбувається мимовільно, і саме тому супроводжується вивільненням енергії. У свою чергу, мимовільний рух $e^{-}$по ДЛМ можливий завдяки особливому розташуванню ферментативних комплексів, а саме у порядку зниження їх здатності віддавати електрони: найбільшу здатність віддавати електрони має HАДH+ $+\mathrm{H}^{+}$(I комплекс), а найменшу $-\mathrm{O}_{2}$ (IV комплекс). У кінцевому результаті процес перенесення електронів по ферментативній системі дихального ланцюга мітохондрій супроводжується зниженням вільної енергії Гібса $(\Delta \mathrm{G})$ і демонструє один із прикладів ендергонічних реакцій у живій системі.

Концентраційний та електричний градієнти, що виникають у результаті транспортування протонів у міжмембранний простір мітохондрій, забезпечують формування протонного електрохімічного потенціалу $\left(\Delta \mu \mathrm{H}^{+}\right)$, який і $\epsilon$ джерелом енергії для синтезу АТФ у процесі окисного фосфорилювання. Розглядаючи пункти спряження дихального ланцюга мітохондрій з окисним фосфорилюванням, викладач спирається на знання студентів щодо механізмів 
функціонування спряжених процесів, отриманих у курсі біофізики. Процес роботи АТФ-синтетази також візуалізуємо з використанням комп’ютерних анімаційних роликів.

Ще один момент даного питання інтегрується 3 тематикою курсу біологічної фізики - функціонування АТФ/АДФ-антипорта. Механізм та види активного транспорту вивчаються в темі «Біофізичні основи мембранних процесів», тому студентам достатньо лише актуалізувати цю інформацію.

Вивчаючи механізм функціонування дихального ланцюга мітохондрій та синтезу АТФ шляхом окисного фосфорилювання в еукаріотичних клітинах, необхідно звернути увагу студентів на особливості перебігу цих процесів на клітинних мембранах бактерій.

Особливе значення для майбутніх фармацевтів має питання мікросомального окиснення в контексті механізмів знезараження ксенобіотиків, у тому числі лікарських засобів. Біотрансформація лікарської речовини в організмі розглядається в курсі фармакології в розділі «Фармакодинаміка», натомість із молекулярними механізмами цього процесу студенти повинні знайомитися саме під час вивчення біохімії. У даній темі акцентуємо лише на відмінностях у локалізації ферментативних систем та перебігу процесів окисного фосфорилювання та мікросомального окиснення. Детальний розгляд тканинного та клітинного метаболізму лікарських засобів розглядаємо в темі «Основи фармацевтичної біохімії».

Міждисциплінарну інтеграцію демонструємо при вивченні питання вільнорадикального окиснення, а саме вказуємо на значення активних форм кисню (супероксид $\mathrm{O}_{2}$ - та пероксид $\mathrm{H}_{2} \mathrm{O}_{2}$ ) у процесі фагоцитозу. Водночас наголошуємо на лікарських засобах антиоксидантної дії: природних біоантиоксидантах, перш за все, вітамінах та синтетичних їх аналогах (наприклад, дибунол, пробукол тощо).

Широкі можливості міждисциплінарної інтеграції дозволяє реалізувати питання щодо речовин, які впливають на енергетичний обмін у клітинах. Оперуючи знаннями з таких навчальних дисциплін, як «Мікробіологія з основами імунології» та «Фармакологія», які вивчаються паралельно, пропонуємо студентам заповнити таблицю 1.

Таблиця 1. Інгібітори електронного транспорту та окисного фосфорилювання

\begin{tabular}{|c|c|c|c|}
\hline $\begin{array}{c}\text { Речовина, що є } \\
\text { інгібітором }\end{array}$ & Процес, який інгібує & Джерело (де синтезується) & $\begin{array}{c}\text { Біологічне значення та } \\
\text { практичне використання }\end{array}$ \\
\hline $\begin{array}{l}\text { Олігоміцин } \\
\text { (антибіотики) }\end{array}$ & $\begin{array}{l}\text { Блокує функціонування } \\
\text { АТФ-синтетази та } \\
\text { перетворення АДФ на АТФ }\end{array}$ & $\begin{array}{l}\text { Актинобактеріями роду } \\
\text { Streptomyces }\end{array}$ & $\begin{array}{l}\text { Антимікробний захист бактерій. } \\
\text { Застосовують при лікуванні } \\
\text { туберкульозу }\end{array}$ \\
\hline $\begin{array}{l}\text { Антиміцин А } \\
\text { (антибіотик) }\end{array}$ & $\begin{array}{l}\text { Блокує дихальний ланцюг } \\
\text { мітохондрій на рівні } \\
\text { переносу електронів через } \\
\text { комплекс III (цитохром b - } \\
\text { цитохром с1) } \\
\end{array}$ & $\begin{array}{l}\text { Актинобактеріями роду } \\
\text { Streptomyces }\end{array}$ & Антимікробний захист бактерій \\
\hline $\begin{array}{l}\text { Пієрицидин А } \\
\text { (антибіотик) }\end{array}$ & $\begin{array}{l}\text { Блокує функціонування } \\
\text { комплексу I у мітохондріях } \\
\text { і бактеріях }\end{array}$ & $\begin{array}{l}\text { Виявлений у Streptomyces } \\
\text { mobarfaensis }\end{array}$ & $\begin{array}{l}\text { Антимікробний захист бактерій. } \\
\text { Здійснюються дослідження щодо } \\
\text { використання пієрицидину А } \\
\text { в якості високоселективного } \\
\text { протипухлинного засобу }\end{array}$ \\
\hline $\begin{array}{l}\text { «Мишачий» } \\
\text { гістотоксин }\end{array}$ & $\begin{array}{l}\text { Порушує функціонування } \\
\text { дихального ланцюга }\end{array}$ & Екзотоксин Yersinia pestis & Антимікробний захист бактерій \\
\hline $\begin{array}{l}\text { Амобарбітал } \\
\text { (амітал) } \\
\text { Секобарбітал } \\
\text { (секонал) }\end{array}$ & $\begin{array}{l}\text { Блокує функціонування } \\
\text { комплексу I }\end{array}$ & $\begin{array}{l}\text { Активний фармацевтичний } \\
\text { інгредієнт синтетичного } \\
\text { походження }\end{array}$ & $\begin{array}{l}\text { Застосовуються у фармакології } \\
\text { як снодійні засоби }\end{array}$ \\
\hline
\end{tabular}

Не оминаємо увагою і такі клітинні отрути - інгібітори дихального ланцюга мітохондрій, як ціаніди, монооксид карбону, сірководень, які блокують роботу цитохромоксидазної системи. Хімічні властивості цих сполук вивчаються в курсі неорганічної хімії, а біологічне і практичне їх значення розкриває саме біохімія.

Розглядаючи роз'єднувачі окиснення і фосфорилювання, як приклад наводимо пірогени мікробної природи (наприклад, ліпополісахариди оболо- 
нок грамнегативних бактерій), під впливом яких протонний потенціал витрачається в обхід АТФсинтетази, що призводить до зменшення виробництва АТФ та посиленого продукування тепла.

За доцільне вважаємо звернути увагу і на так звані спряжуючі агенти, які збільшують ефективність роботи ДЛМ. Спряжуючі агенти знаходять широке застосування в медицині в якості лікарських засобів, наприклад, пірацетам, фенібут, мексидол [4]. Механізм дії цих речовин пов'язаний з активацією аденілатциклазної системи в нейроцитах, яка, у свою чергу, підтримує продукування АТФ у безкисневому режимі, а в умовах гіпоксії переводить метаболічні процеси головного мозку в енергооптимальний режим.

Додатково акцентуємо на лікарських засобах, які $€$ складовими дихального ланцюга: субстратами чи коферментами. При багатьох порушеннях біологічного окиснення позитивний вплив має метаболітна (субстратна) терапія, а саме введення в організм глюкози, фруктози, амінокислот, молочної, лимонної, янтарної, яблучної кислот тощо. Коензимами та кофакторами ферментних систем ДЛМ є вітаміни, зокрема нікотинамід, рибофлавін, фармпрепарати флавінату (ФАД) та ФМН. В останні роки для поліпшення тканинного дихання при асфіксії новонароджених, при астматичних станах, хронічній пневмонії, серцевій недостатності, анеміях, деяких отруєннях використовують ферментний препарат цитохром с [4].

Останнє питання лекції «Хімічні перетворення у циклі трикарбонових кислот. Субстратне фосфорилювання» також дає широкі можливості міжпредметної та внутрішньопредметної інтеграції. Перш за все акцентуємо на локалізації ферментативних систем циклу в еукаріотів (матрикс і мембрани мітохондрій) та прокаріотів (цитозоль). Звертаємо увагу на лікарські засоби, які в той чи інший спосіб впливають на перебіг реакцій циклу Кребса. Студенти отримують завдання заповнити таблицю 2.

Таблиця 2. Лікарські засоби, що впливають на реакції циклу Кребса

\begin{tabular}{|c|c|c|c|}
\hline $\begin{array}{l}\text { Лікарський } \\
\text { засіб }\end{array}$ & $\begin{array}{c}\text { Діюча } \\
\text { речовина }\end{array}$ & $\begin{array}{l}\text { Фармакотерапевтична } \\
\text { група }\end{array}$ & Фармакологічні властивості \\
\hline Елфунат & $\begin{array}{l}\text { Етилметил- } \\
\text { гідроксипі- } \\
\text { ридину } \\
\text { сукцинат }\end{array}$ & $\begin{array}{l}\text { Засоби, що впливають } \\
\text { на нервову систему }\end{array}$ & $\begin{array}{l}\text { Викликає посилення компенсаторної активації } \\
\text { аеробного гліколізу та зниження ступеня пригнічення } \\
\text { окисних процесів у циклі Кребса в умовах гіпоксії } \\
\text { з підвищенням вмісту аденозинтрифосфату (АТФ) і } \\
\text { креатинфосфату, активацію енергосинтезувальних } \\
\text { функцій мітохондрій, стабілізацію клітинних мембран }\end{array}$ \\
\hline Стимол & $\begin{array}{l}\text { Цитруліну } \\
\text { малат }\end{array}$ & $\begin{array}{l}\text { Засоби, що впливають } \\
\text { на травну систему та } \\
\text { метаболічні процеси }\end{array}$ & $\begin{array}{l}\text { Цитруліну малат - це еквімолекулярна суміш яблучної } \\
\text { кислоти та цитруліну. } \\
\text { Яблучна кислота стимулює цикл Кребса та активує } \\
\text { механізм утворення енергії на клітинному рівні. } \\
\text { Цитрулін входить до циклу сечовини, активує } \\
\text { утворення та виведення сечовини з організму }\end{array}$ \\
\hline Рибоксин & Інозин & $\begin{array}{l}\text { Кардіологічні } \\
\text { препарати }\end{array}$ & $\begin{array}{l}\text { Посилює активність деяких ферментів циклу Кребса. } \\
\text { Інозин є метаболічним попередником АТФ }\end{array}$ \\
\hline Бенфогама & $\begin{array}{l}\text { Бенфотіамін } \\
\text { (вітамін B1) }\end{array}$ & $\begin{array}{l}\text { Прості препарати } \\
\text { вітаміну В1 }\end{array}$ & $\begin{array}{l}\text { Бере участь у перетворенні } \alpha \text {-кетоглутарату на } \\
\text { сукциніл СоА в циклі лимонної кислоти }\end{array}$ \\
\hline
\end{tabular}

Підсумовуючи лекційне заняття, наголошуємо на необхідності осмисленого розуміння механізмів біохімічних перетворень у живих клітинах та усвідомленні складних взаємозв’язків між ними у процесі функціонування людського організму.

Висновки та перспективи подальших досліджень. Безперечно, реалізація принципів міждисциплінарної інтеграції під час проведення лекційних занять вимагає від викладача глибоких знань не лише його предмета, але й багатьох інших навчальних дисциплін, у тому числі і предметів фа- хової підготовки студентів-фармацевтів. Вкрай важливо дотримуватися оптимального балансу між матеріалом теми, що вивчається під час лекції, та інформацією суміжних тем чи навчальних дисциплін - домінуючим, однозначно, має бути розкриття основних питань заняття. Аналізуючи власний досвід використання принципів міждисциплінарної інтеграції при вивченні такої складної навчальної дисципліни, як біологічна хімія, констатуємо підвищення мотивації студентів, а саме усвідомлення практичної значущості навчального матеріалу та 
набутих компетентностей у майбутній професійній діяльності.

Безумовно, запропоновані в роботі приклади не охоплюють усіх теоретичних та практичних можливостей реалізації принципів міждисциплінар-

\section{Список літератури}

1. Біологічна хімія з біохімічними методами досліджень / О. Я. Скляров, Н. В. Фартушок, А. Д. Сойка, I. С. Смачило. - К. : Медицина, 2009. - С. 14-35.

2. Біологічна хімія / [Л. М. Вороніна, В. Ф. Десенко та ін.]. - Х. : Вид-во «Основа» НФаУ, 2000. - С. 47-48.

3. Бухальська С. Теоретичні аспекти реалізації міжпредметної інтеграції в процесі викладання медичної біології у вищих медичних навчальних закладах / С. Бухальська, Н. Шамро // Нова педагогічна думка : наук.метод. журн. - 2015. - № 1 (81). - С. 92-95.

4. Воронина Т. А. Антиоксидант мексидол. Основные нейропсихотропные эффекты и механизм действия / Т. А. Воронина // Психофармакол. Биол. Наркол. 2001. - T. 1, № 1. - С. 2-12.

5. Губський Ю. І. Біологічна хімія : підручник / Ю. І. Губський. - К. ; Тернопіль : Укрмедкнига, 2000. C. 12-16, 36-38.

6. Карпець М. В. Міждисциплінарна інтеграція - основа професійної спрямованості навчання / М. В. Карпець // Світ медицини та біології. - 2016. - № 4 (58). C. 144-147.

7. Кирвас В. А. Горизонтальная междисциплинарная интеграция при формировании информационно-коммуникационной компетентности студентов / В. А. Кирвас, П. Э. Ситникова // Системи обробки інформації : зб. наук. праць. - Х. : Харківський університет Повітряних Сил імені Івана Кожедуба, 2016. - Вип. 2 (139). С. $212-215$.

\section{References}

1. Skliarov, O.Ya., Fartushok, N.V., Soika, A.D., \& Smachylo, I.S. (2009). Biolohichna khimiia z biokhimichnymy metodamy doslidzhen [Biological chemistry with biochemical methods of research]. Kyiv: Medytsyna [in Ukrainian].

2. Voronina, L.M., \& Desenko, V.F. (2000). Biolohichna khimiia [Biological chemistry: Textbook]. Kharkiv: Osnova [in Ukrainian].

3. Bukhalska, S., \& Shamro, N. (2015). Teoretychni aspekty realizatsii mizhpredmetnoi intehratsii v protsesi vykladannia medychnoi biolohii u vyshchykh medychnykh navchalnykh zakladakh [Theoretical aspects of implementation of crosscurricular integration in the teaching of medical biology in higher medical institutions]. Naukovo-metodychnyi zhurnal "Nova pedahohichna dumka" - Scientific and methodological journal "New Pedagogical Thought”, 1 (81), 92-95 [in Ukrainian]. ної інтеграції при викладанні біологічної хімії. Перспективним, на наш погляд, є аналіз можливостей створення та реалізації наскрізних програм для закладів вищої освіти I-II рівнів акредитації та фахових коледжів.

8. Лисаченко О. Д. Роль міждисциплінарної інтеграції у формуванні клінічного мислення студента / О. Д. Лисаченко // Вісник проблем біології і медицини. - 2012. Вип. 3, т. 2 (95). - С. 133-135.

9. Міждисциплінарна інтеграція викладання біоорганічної хімії в медичному університеті / Е. Ю. Рождественський, М. С. Сидун, А. Г. Кривобок [та ін.] // Акт. пробл. суч. медицини: Вісн. Укр. мед. стоматол. академії. - 2009. - Т. 9, вип. 4 (ч. 3). - С. 249-251.

10. Міждисциплінарна інтеграція як складова проблемно-орієнтованого навчання у медичному університеті / А. Г. Шульгай, Л. Я. Федонюк, А. Є. Мудра, О. М. Олещук // Медична освіта. - 2018. - № 4. - С. 113116. - URL : https://ojs.tdmu.edu.ua/index.php/med_osvita/ article/view/9342.

11. Міждисциплінарна інтеграція як фактор удосконалення викладання фармакології у медичному виші / Н. І. Волощук, О. С. Пашинська, А. О. Іваниця, І. В. Таран // Медична освіта. - 2016. - № 4. - C. 8. - URL : http:// nbuv.gov.ua/UJRN/Mosv_2016_4_4.

12. Прошкін В. В. Інтеграція університетської науки й освіти: історичний аспект / В. В. Прошкін // Педагогічна наука: історія, теорія, практика, тенденції розвитку : е-журнал. - 2010. - № 2. - Режим доступу : http:// intellect-invest.org.ua/pedagog_editions_e-magazine_ pedagogical_s...

4. Voronina, T.A. (2001). Antmoksydant meksydol. Osnovnye neyropsykhotropnye effekty i mekhanizm deystviya [Antioxidant Mexidol. The basic neuropsychotropic effects and mechanism of action]. Psykhofarmakol. Biol. Narkol. Psychopharmacol. Biol. Narcol., 1 (1), 2-12 [in Russian].

5. Hubskyi Yu.I. (2000). Biolohichna khimiia: Pidruchnyk [Biological Chemistry: Textbook]. Ternopil: Ukrmedknyha [in Ukrainian].

6. Karpets, M.V. (2016). Mizhdystsyplinarna intehratsiia - osnova profesiinoi spriamovanosti navchannia [Interdisciplinary integration - the basis of professional orientation training]. Svit medytsyny ta biolohii - The World of Medicine and Biology, 4 (58), 144-147 [in Ukrainian].

7. Kyrvas, V.A., \& Sytnykova, P.E. (2016). Gorizontalnaya mezhdystsyplinarnaya integratsiya pri formirovanii informatsyonno-kommunikatsyonnoy kompetentnosti studentov [Horizontal interdisciplinary integration in the formation of 
students' information-communication competence]. Systemy obrobky informatsii: zbirnyk naukovykh prats. - Information Processing Systems, 2 (139), 212-215 [in Russian].

8. Lysachenko, O.D. (2012). Rol mizhdystsyplinarnoi intehratsii u formuvanni klinichnoho myslennia studenta [The role of the interdisciplinary integrations in the formation of the clinical thinking of students]. Visnyk problem biolohii i medytsyny - Bulletin of Problems of Biology and Medicine, 3, 2 (95), 133-135 [in Ukrainian].

9. Rozhdestvenskyi, E.Yu., Sydun, M.S., \& Kryvobok, A.H. (2009). Mizhdystsyplinarna intehratsiia vykladannia bioorhanichnoi khimii v medychnomu universyteti [Interdisciplinary integration in bio-organic chemistry teaching at the medical university]. Akt. probl. such. medytsyny: Visn. Ukr. med. stomatol. akademii. - Actual Problems of the Modern Medicine: Bulletin of Ukrainian Medical Stomatological Academy, 9, 249-251 [in Ukrainian].

10. Shulhai, A.H., Fedoniuk, L.Ya., Mudra, A.Ye., \& Oleshchuk, O.M. (2018). Mizhdystsyplinarna intehratsiia yak skladova problemno-oriientovanoho navchannia u medychnomu universyteti [Interdisciplinary integration as a part of problem-based learning in the medical university]. Medychna osvita - Medical Education,4, 113-116. Retrieved from: https://ojs.tdmu.edu.ua/index.php/med_osvita/article/ view/9342 [in Ukrainian].

11. Voloshchuk, N.I., Pashynska, O.S., Ivanytsia, A.O., \& Taran, I.V. (2016). Mizhdystsyplinarna intehratsiia yak faktor udoskonalennia vykladannia farmakolohii u medychnomu vyshi [Interdisciplinary integration as an improving factor of teaching pharmacology in medical universities]. Medychna osvita - Medical Education, 4, 8-11. Retrieved from: http://nbuv.gov.ua/UJRN/Mosv_2016_4_4 [in Ukrainian].

12. Proshkin, V.V. (2010). Intehratsiia universytetskoi nauky y osvity: istorychnyi aspekt [Integration of university science and education: historical aspect]. Pedahohichna nauka: istoriia, teoriia, praktyka, tendentsii rozvytku Pedagogical Science: History, Theory, Practice, Development Trends, 2. Retrieved from: http://intellect-invest.org. ua/pedagog_editions_e-magazine_pedagogical_s... [in Ukrainian]. 